\title{
LABOUR CONFLICT AND THE PERSISTENCE OF MACRO UNDEREMPloyment in South Africa
}

\author{
CH Schoeman, I Botha \& PF Blaauw* \\ Department of Economics and Econometrics, University of Johannesburg \\ Accepted June 2010
}

Something must be structurally wrong in a labour market when a well developed economy like that of South Africa is not able to absorb and allocate an accumulating surplus of labour over a period of 20 years or longer but has instead moved to the use of more capital-intensive technology. The objective of this paper is to analyse the role labour conflict plays in the persistence of macro underemployment in South Africa. For the analysis two models identified from the literature were used. In these models labour conflict originates from an over-regulated labour market where labour appropriates capital and bad or hostile labour relations. In both models the switch to technology leads to underemployment. It was found that bad labour relations contribute to the persistence of underemployment in South Africa.

JEL E24, J51, 52

\section{Introduction}

The long period of positive economic growth, relatively low interest rates, low inflation and positive business sentiment has not been reflected in job creation in South Africa. Amidst a condition of rising employment and unemployment levels, the South African economy has also seen a significant increase in atypical employment since the mid-1990s. This includes arrangements such as outsourcing, labour brokering and part-time contracts (Bhorat \& Van der Westhuizen, 2009: 3).

Gupta and du Toit (2009: 8) emphasise the skills shortage as well as high fixed costs of hiring as the main sources of unemployment. The South African labour market has also been subjected to the long run effects of structural shifts as well as technological change in the economy. The structural shift caused a shift in output away from the primary sectors towards the service sectors of the South African economy (Bhorat, 2004: 944). The technological adjustment referred to the advent of the micro- electronics revolution as well as significant increases in the capital/labour ratios (Bhorat, 2004: 945-946).

Previous research shows that a possible reason for this phenomenon lies in sunk cost associated with and/or uncertainty about labour in South Africa (Schoeman \& Blaauw, 2007). It is suspected that the associated sunk cost and/or uncertainty about labour stems from a history of labour conflict in South Africa. The macro underemployment referred to in this paper, as reflected in the a high and persistent level of unemployment, is seen as a consequence of an intentional decision by firms, not driven by efficiency considerations, to substitute labour with capital in the production process.

In this paper persistence is seen as the result of a continued presence of factor effects that initiate the original decision to shift to technology in favour of labour. Labour conflict, the long-run nature of technology choice (the irreversibility of fixed investment), the limited scope to employ labour once the technology choice has been made (inflexibility of capital), capital deepening, slow renovation of capital 
and technology sclerosis, all result in inefficient factor allocation and macro underemployment (Caballero \& Hammour, 1997; Blanchard \& Phillipon, 2006). The objective of this paper is therefore to analyse the possibility that labour conflict is a major contribution to the persistence of macro underemployment (referred to as underemployment in the rest of the paper) and highly stable unemployment in South Africa.

This study sets out to determine what influences a firm's decision in favour of new technology over labour. It is probable that the same factors that influenced past decisions on substituting labour with capital are still present in decisions on technology, and, therefore, will continue to influence the persistence of underemployment. The hypothesis of this paper is that labour conflict in South Africa contributes to the persistence of underemployment in South Africa.

The paper will first analyse recent literature on the role of labour conflict in the creation of underemployment and high unemployment equilibrium levels. The applicability of the theories and results will be interpreted for South Africa. The results will act as a basis for an empirical analysis of the role played by labour conflict in the persistence of underemployment in South Africa.

\section{2}

\section{Literature overview}

The channels by which labour conflict contributes to underemployment and high equilibrium levels of unemployment will be analysed in this section. Two traditions are involved in labour conflict in unemployment, are Classical and Marxist. The role played by power and conflict in employment is traditionally suppressed in Classical economic theory by assuming noncooperative bargaining in competitive markets by multiple rational optimising and anonymous agents (labour and firms). The agents are price takers with no power over prices and quantity makers with complete power over quantities. The agents can therefore buy and sell any quantity at the going rate. These assumptions ensure a (powerless, harmonious) economic world of full employment equilibrium.
Evidence on increased labour power, labour conflict and the persistence of unemployment are accommodated in adapted models of the Classical theory. Labour power in these adaptive versions can lead to medium-run unemployment. In the first model the increased labour power and associated overpricing of labour lead to disenfranchised labour that cannot exert demand pressure on wages and to short-run underemployment. In the second model the increase in labour power leads to a temporary increase in interest, and a decrease in investment and growth, which results in medium-run unemployment. The assumption in this model is that the propensity to save is higher through profits than wages. The underlying economic reality (structure of the labour and commodity markets respectively) will ensure a return to long-run full employment equilibrium (Hicks, 1974; Layard, Nickell \& Jackman, 1991 and Friedman, 1968: 9)

Conflict as a determinant of high levels of equilibrium unemployment and persistent underemployment originates from and is central to the Marxian tradition. Broadly underlying the tradition and related theories is the assumption of an environment of cooperative bargaining, where historical (past distributional outcomes) and social elements (custom) motivate wage and profit aspirations. According to this tradition equilibrium underemployment is the result of employer power or command over labour (control of labour effort) that originates from the existence of continuous underemployment, employment rent (resulting in job losses constituting a cost for labour) and endogenous technology.

In most economies, institutions administer and manage the functioning of the labour market. The institutions in question include: employer and employee organisations, the courts of law including specialist courts, institutions of dispute resolution, ministries of labour or employment, collective bargaining institutions and tripartite institutions (Bhorat \& Van der Westhuizen, 2009: 19). The various influencing factors are all time and context-dependent. This will fundamentally change the way in which labour regulatory stipulations provisions impact on the broader economy (Bhorat \& Van der 
Westhuizen, 2009: 19). History and sociology determine the institutional arrangements that govern these labour market particulars, and their effects on wage and profit rates (distribution of income) and employment.

Firms own and control technology and the technology choice is aimed at maximising profit. Firms may, in reaction to conflict with labour over new demands on the distribution of income, choose inefficient technology (capital deepening), which results in underemployment and reduces income as long as the greater part goes to profit. Through technology choice conflict in the labour market can therefore result in persistent underemployment. Multiple underemployment equilibriums determined by historic and social considerations are therefore possible (Bowles \& Gintis, 1990; Hicks, 1974 and Skott, 1991).

Labour conflict has different dimensions and, in the interest of analytical clarity, is divided here into two forms, namely distributional and relational conflict. Two recent studies investigated how these different forms of labour conflict can affect equilibrium unemployment (Caballero \& Hammour, 1997 and Blanchard \& Phillipon, 2006). This paper borrows from both. Labour conflict in these two theories leads to inefficiencies in production and to underemployment. In their study, Caballero and Hammour (1997) find that conflict in the distribution of income can, because of a substantial buildup of institutions in favour of labour (intervention in favour of labour), lead through a shift in technology to underemployment. Blanchard and Phillipon (2006) find that the quality of labour relations or relational conflict rather than institutional buildup in favour of labour, results in countryunique unemployment equilibriums.

Caballero and Hammour (1997; the $\mathrm{CH}$ model) view distributional conflict, in the form of the appropriation of capital by labour, as the cause of inefficiency in production. This results in underemployment. The outcome of appropriability depends on the respective supply elasticities of labour and capital, the degree to which they need each other in production and institutional buildup in favour of labour. The low elasticity of capital in the short run makes it possible for labour to then appropriate capital (growth of the labour share in production in expense of capital) through the institutional buildup in favour of labour. However, in the long run, capital is much more flexible and will develop new, less labour-intensive technologies that will guarantee capital returns equivalent to what capital can get elsewhere in the world. Investment and unemployment will increase over the longer run. The cost in this inefficient allocation of labour and capital will in the long run be carried by labour in the form of a decrease in labour share and greater unemployment in favour of a recovery in capital profitability. The inefficiency in production will result in underemployment, excessively slow renovation of capital and technological sclerosis. The latter is because of the increase in the duration of unemployment that leads to falling shadow (reserve) wages or increased costs of unemployment, downward pressure on wages and therefore lower pressure to scrap less productive units.

Instead of hiring more labour at lower wages, as predicted by classical theory, firms instead choose to over-use existing capital units. Labour is worse off and capital better off under conditions of underemployment. The new unemployment equilibrium is not dependent on the factors that created it anymore and is primarily the result of inefficient factor allocation because of a switch in production technology in favour of long-run inflexible capital because of these factors. Labour will not share in increased investment and growth in a heavily regulated market.

A comparative study done on countries with similar formal institutions and economic environments shows that these countries experience different (idiosyncratic) levels of unemployment (Blanchard \& Phillipon, 2006). The cause of these discrepancies lies in the various labour histories of these countries. The study finds that the quality of labour institutions arising from labour history rather than formal labour institutions per se is the reason for these differences and idiosyncratic equilibrium rates of unemployment. According to Blanchard and Phillipon (2006; the BP Model), equilibrium unemployment in a country 
is the combined result of a history of bad or hostile labour relations driven by countryspecific characteristics (the state's historic attitude to early unions in the 19th century in Europe for instance, or in general, the origin, purpose, development and nature of these institutions).

Relatively high equilibrium rates of unemployment are associated with a history of hostile labour relations that resulted in a period of frequent bargaining failures and a high frequency of strikes. This situation incurs costs and creates uncertainty about labour and future production. Adverse shocks increase uncertainty at firm level and exacerbate the situation even further. The bargaining failures accompanied by strikes result in high cost (dead weight loss) and lower surplus for the firms to allocate, leaving them even more prone to future strikes. Labour becomes a high cost and uncertain production factor for the firm. The endogenous nature of technology makes it possible for the firm to switch to more certain or less risky capital in the form of capital-intensive technology. Once the switch has taken place uncertainties and cost are hedged in long-run inflexible capital. Adverse shocks, bad labour relations and strikes no longer have the same effect on employment. The resultant underemployment then becomes equilibrium unemployment.

Current hostile labour relations and underemployment in this model are associated with a high levels of strikes in the past. A causal relationship exists between the quality of labour relations, adverse shocks, the cost of strikes, uncertainty about productivity, as well as the switch to technology and equilibrium underemployment. The quality of labour relations depends on the degree of trust in the economy and is based on the reputation of truth telling (on productivity and surplus to be divided between capital and labour) of firms. Bargaining failures as expressed by strike activity is an indication of firms' reputations, labour's militancy and the quality of labour relations in the country in general. High strike activity is positively related to labour militancy and negatively related to the reputation of the firms, the degree of trust, the quality of labour relations and employment (Blanchard \& Phillipon, 2006).
Countries with bad labour relations have comparatively higher rates of unemployment equilibrium (Blanchard \& Phillipon, 2006). Labour will not share in increased investment and growth in a hostile labour market. Heavily regulated labour markets (intervention in favour of labour) are therefore not the reason per se for underemployment but rather the way in which these institutions were used for the settlement of historical conflict.

Both the $\mathrm{CH}$ and BP models implicitly or explicitly address economic, historical, and sociological aspects related to labour conflict as factors to explain equilibrium underemployment. Both models also give an explanation of the switch to technology through which distributional and relational conflict can create inefficiency in factor allocation and underemployment. Distributional conflict for the $\mathrm{CH}$ model originates from institutional buildup in favour of labour and the appropriation of capital, while for the BP model relational conflict stems from bad labour relations. In both cases, the result is new equilibrium levels of underemployment.

\section{3}

\section{Labour conflict and the shift in production technology in South Africa}

Distributional and relational conflict in South Africa will be analysed in this section. Events in the labour history will be interpreted to give a general understanding of those characteristics concerning labour conflict that are specific to South Africa. The section will analyse and interpret events running up to the 1980 s and 1990s, which are characterised as periods of great transformation and the institutionalisation of the labour market in South Africa. The 1970s in South Africa, however, marked the start of increasing unemployment, which led to the current high level of unemployment. Common characteristics of labour relations in South Africa are historical racial conflict, low levels of trust and then open conflict between labour and business since the 70s. Evident from the beginning of the $70 \mathrm{~s}$ is the substantial 
institutional buildup in favour of labour, open labour militancy, periodic strikes, continuous increase in the capital/output ratio and the start of continued increasing unemployment.

\subsection{Institutional buildup, appropriation, bad labour relations and uncertainty about labour in South Africa}

Labour market history in South Africa is overshadowed by racially dominated politics, institutionalised racial labour structures, and, since the seventies, open racially based labour market conflict. This means that the wages the market naturally reflected have historically been seen by labour as more of a customary or race-based convention than as a reflection of the interaction between the supply and demand for skilled and unskilled workers (Fick \& High, 1987). The historical reason for this is the racially based policies of government, legislation, unions and the division between white skilled labour, at best passive concentrated overwhelming white business favoured by government up to 1994, and unskilled black labour. The 1980s were characterised by increased institutional buildup in favour of unskilled labour, primarily to resolve labour conflict through business by renegotiating labour share in production.

The increased regulation of the labour market gave labour a strong platform not only to negotiate better wages but also to drive political goals (Jones \& Inggs, 1994). By the end of 1977 , between 55000 and 70000 workers out of a total black workforce of 7 million were believed to belong to 27 unregistered black trade unions. This represented about one percent of the total black workforce. In 2005 the figure was around 3 million trade union members - about 40 per cent of the formally employed labour force, excluding the agricultural sector, domestic workers and self-employed persons. This represents an annual increase of nearly 6 per cent. According the International Labour Organisation, this is the highest increase among the 92 countries that it surveyed in its annual study of the world's labour markets (Barker, 2007: 93).

The gradual institutional buildup in favour of labour started in 1973 after unaccustomed demonstrations by workers in the Natal textile industry and legislation in the form of the Bantu Labour Relations Act. In the end, the strikes involved an estimated 60000 to 100000 black employees from the brick, textile chemical, rubber, iron, steel, electrical services and municipal service in Durban and surrounding areas (Van der Velden \& Visser, 2006). In reaction to the demonstrations, provision was made for a committee of non-union representation on the enterprise level. In 1977, the government appointed a commission (the Wiehahn Commission) to enquire into labour legislation. The majority of the Commission's proposals were accepted. The report included proposals on the registration of black trade unions and the abolition of statutory job reservation (Van der Velden \& Visser, 2006). The inclusion of the proposals in the Labour Relations Act in 1979 marked the beginning of the growth of black trade union movement and their political influence.

The trade union movement in South Africa is a powerful one. It has aligned itself with the new government in South Africa. Furthermore, there is an institutional framework - the Bargaining Councils and Wage Boards - to set minimum wages in much of the formal sector (Kingdon \& Knight 2001a: 5-6). These regulations are extended to all firms in the industry, irrespective of size (Kingdon \& Knight, 2001b: 9-10). Kingdon and Knight (2001a: 5-6) further raise the point that it would be interesting to see whether this implies that wages will be less responsive to local unemployment conditions than in countries with weaker unionisation and weaker wage-setting institutions.

In a relatively short period the unions, led by the Congress of South African Trade Unions (which represented both industrial and general worker unions under one umbrella), developed into a formidable economic and political force. The political agenda of the black unions was explicitly foregrounded when it confronted state policy on a number of issues. One element of the agenda was a vote for disinvestment in South Africa. This development also pulled business into the political arena (Fick \& High, 1987). Increased pressure on foreign companies to sign the Sullivan code and lobbying by Cosatu 
to disinvest led to the pull-out of a significant number of US firms (including IBM, Coca Cola, and General Motors). The role of trade unions in South African society therefore became increasingly political in nature. Trade unions were seen as a vehicle for liberation from oppression. From 1973 labour and since the 80s unions like the National Union of Mineworkers (NUM) grew rapidly and steadily became more militant. This culminated in a three-week strike in 1987. The intensity of the conflict and militancy of labour is reflected in the fact that nine people were killed and 500 injured during this strike.

Organised business was not ready for militant black trade unions. The new industrial relations system did not contribute much to the establishment of sound collective relationships at the time. It was seen rather as a frame of reference for conflict handling, whereby employers tried to restrict conflict and the government resorted to the tactic of buying time (Slabbert, 1999). The period 1973 to 1987 was characterised by the increase in labour unrest, real wages and labour share in production. Strikes during this time increased rapidly to reach a high in 1987. Real wages for Africans in the non-primary sector rose by 2,9 per cent per annum on average between 1975 and 1990 (Hofmeyr, 1994). This indicates that conflict was not only political but also related to the distribution of income.

The change in the political dispensation in 1994 gave extra momentum to labour in the form of government's alliance with labour, greater political intervention, and the introduction of minimum wages, social charges on payrolls and job protection through legislation (Kingdon \& Knight 2001a: 5-6; Kingdon \& Knight 2001b).

The relatively quick and radical changes in the field of labour created a lot of uncertainty for business. This included the militancy of labour, newly formed unions, the rapid development of unions into formidable political and economic forces, the historical absence of a formal collective framework to handle conflict between labour and business and the political nature of the labour conflict. History also did not leave labour with much reason to trust business. The overall uncertainty was aggravated by historical adverse shocks of increasing political instability, the debt crisis, sanctions, disinvestment, increased internal war effort and the beginning of globalisation.

\subsection{The changing role of capital in production in South Africa since the 70s}

According to Bhorat and Hodge (1999), since the 1970s a structural change in the economy and a technological change in production (greater capital intensity) were evident in individual sectors of the economy. The capital deepening had its biggest effect on the primary and secondary sectors while microelectronics mostly impacted on the service sectors. The findings illustrate the direct and indirect roles played by technical change (more capitalintensive technologies) within sectors with poor job creating ability, especially in the lower skilled occupations of the formal sector and unemployment since the mid-eighties. Bhorat and Hodge (1999) suggest that the changes in production methods may partly be a consequence of trade liberalisation and a search for efficiency, which led to unemployment in previously protected manufacturing industries. However, it is uncertain to what extent trade liberalisation contributed to these changes.

Studies done by Van Dijk (2003) and McCarthy (2005) indicate that the change in technology did not resolve the problem of relatively low total factor productivity. The relative performance in productivity has in fact decreased since 1970. It therefore seems that the reason for the shift in technology was not to implement more efficient technology but was driven by factors other than efficiency considerations alone. If the shift was aimed at greater efficiency, productivity would have caught up or at least led to a relatively stable gap in productivity after the shift. According to Van Dijk (2003) and McCarthy (2005) the reason for the inefficiency lies in ideology and politics. This took the form of strict import substitution to build large capital investments at the cost of labour (Van Dijk, 2003) and political ideology (McCarthy, 2005) that constrained, and still constrains market forces. Factors other than classical economic ones only, impact on 
inefficient factor allocation and relatively low total productivity in South Africa. The decision to shift to more capital-intensive technology was not a classical economic decision, it seems, but was influenced and may still be influenced by non-economic considerations.

\section{4 \\ Evidence on labour conflict, the substitution of labour and the persistence of underemployment in South Africa}

Bhorat and Hodge (1999) found that the increased use of capital in the method of production or capital deepening did change the nature of the demand for labour and did contribute to the large pool of unemployed, especially among the unskilled in South Africa. It is evident from the empirical analysis that hostile labour relations did contribute (and continue to do so) to the use of capital-intensive technology. Although capital deepening did change the nature of demand for labour, which in turn contributed to unemployment, it is labour militancy that translates into unemployment. The labour militancy contributes to the continued inefficient factor allocation, which results in the persistence of underemployment in South Africa. The long period of economic growth, relatively low interest rates, low inflation and positive business sentiment is therefore not reflected in job creation in South Africa (see also Caballero \& Hammour, 1997, on this).

Previous research (Schoeman, Blaauw \& Pretorius, 2008; Schoeman \& Blaauw, 2007) indicates that unemployment is endogenously determined by economic as well as institutional factors in South Africa and that sunk costs and uncertainty about labour as a production factor in combination with extreme adverse historical shocks in the eighties possibly led to the unemployment that we now experience. It is therefore possible that the associated sunk costs due to an institutional buildup (intervention) in favour of labour and uncertainty about labour because of the history of labour conflict could have influenced the structure of labour demand that led to a movement in the production process away from labour, to capital. Uncertainty about labour can result in more capital-intensive technology or capital deepening even in the longer run. It is therefore possible that distributional as well as relational conflict could have created sunk costs (the introduction of minimum wages, social charges on payrolls and job protection through legislation) and uncertainty about labour that resulted in the substitution of labour with capital - and hence underemployment in South Africa.

\subsection{Empirical analysis of labour conflict and unemployment in South Africa}

\subsubsection{Specification of the model}

The limitations of this type of study are misspecification. A simultaneous equation model to simulate unemployment in South Africa may be more appropriate. Dummies also carry all the subjectivity of their creator. Furthermore, the possibility exists that the dummies may continuously or periodically overor under-accentuate the qualitative information they carry and, in addition, the information a dummy is carrying may be incomplete for the same reason. Previous research, in which underlying theory has proven to be the basis on which the dummies are defined and the conformation of results to theory and reality which it is trying to explain is bounded by this probability. According to Rogers (1989), the key feature of partial equilibrium analysis as applied in this study is its notional ability to determine causality, even on the macro level. Well-founded simple and elegant partial equilibrium analysis can therefore contribute to the understanding of certain economic phenomena.

Labour conflict in this paper is divided into two forms namely distributional and relational conflict. This is based on two studies that investigated how these two forms of labour conflict affect equilibrium unemployment (Caballero \& Hammour, 1997; Blanchard \& Phillipon, 2006). The findings of these studies are that labour conflict leads to inefficiencies in production and underemployment.

The $\mathrm{CH}$ model finds that conflict through institutions in favour of labour, through a shift 
in technology, leads to underemployment. The appropriation of capital by labour is the cause of inefficiency in production and underemployment. The outcome of appropriability depends on the respective supply elasticities of labour and capital. Low capital elasticity in the short-run makes it possible for labour to appropriate capital.

The BP model finds that relational conflict in favour of labour results in country unique unemployment equilibrium. High unemployment is associated with a history of hostile labour relations that resulted in a period of frequent bargaining and a high frequency of

$Y_{t}=\alpha_{0}+\beta_{1} X_{1}+\beta_{2} X_{2}+\beta_{3} X_{3}+\beta_{4} D_{1}+\beta_{5} D_{2}+\varepsilon_{t}$

Where:

$Y_{t}=$ Capital/output ratio $(\mathrm{CO})$

$X_{1}=$ Labour share (LS)

$X_{2}=$ Frequency of strikes (STRIKES)

$X_{3}=$ Real interest rate (RR)

$D_{1}=$ institutional dummy (DUM)

$D_{2}=$ HIV/AIDS prevalence dummy (AIDS)

The capital/ output ratio is used as the dependent variable since it gives a good indication of the role capital plays in production. The frequency of strikes was used as a proxy for the relational conflict variable (BP model) and the compensation of employees to gross value added ratio was used as a proxy for the distributional conflict variable to represent labour share ( $\mathrm{CH}$ model). A dummy variable was created for intervention by institutions in favour of labour. It was based on important historical events or legislation that occurred in the South African labour market. Virtually all of the institutional developments after 1973 were in favour of labour as a production factor (See exposition of rationale in 3.1). Table 1 provides a summary of the events deserving of a pro-labour classification of the institutional dummy variable.

A new dummy for each individual piece of legislation was also considered. However, the effect of each piece of legislation is not calculated after only one period. The aim of the paper is to focus on the general impact of labour strikes. This result is a switch to capital-intensive technology. Once the switch has taken place uncertainties and cost were hedged in long-run inflexible capital. Relational conflict then no longer has the same effect on employment underemployment then becomes equilibrium unemployment.

Both these models result in new equilibrium unemployment due to a switch to capitalintensive technology. To determine if such a switch to capital intensive technology in South Africa is eminent, distributional and relational conflict as explanatory variables will be used to explain the capital/ output ratio in South Africa.

legislation and therefore a single institutional dummy was preferred. Every time such an occasion was deemed to have a favourable outcome for labour as a production factor, a value of 1 was given to the variable.

The real interest rate and the HIV/AIDS prevalence dummy were used as control variables for possible specification bias. It was assumed that HIV/AIDS prevalence started in 1990 because according to UNAIDS/WHO (2006), between 1990 and 2003 - a period during which HIV/AIDS prevalence in South Africa increased dramatically - the country fell by 35 places in the Human Development Index.

Data were used on an annual basis from 1970 to 2004. The capital/output ratio, compensation of employees, gross value added, interest rates and the inflation rate were obtained from the South African Reserve Bank data bank via Quantec Research. The frequency of strikes was obtained from Dr Sjaak van der Velden. $\mathrm{He}$ is a researcher at the International Institute for Social History in Amsterdam, Holland (Van der Velden, 2009). 


\section{Table 1}

Institutional developments deserving of a pro-labour classification of the institutional dummy variable

\begin{tabular}{|c|c|}
\hline Year & Institutional development \\
\hline $1960-1972$ & No significant developments \\
\hline 1973 & Amendment - Bantu Labour Relations Act \\
\hline 1974 & Trade Union Advisory and Coordinating Council \\
\hline 1975 & Amendment - Coloured Person Representative Council Act \\
\hline \multicolumn{2}{|l|}{1976} \\
\hline \multicolumn{2}{|l|}{1977} \\
\hline \multicolumn{2}{|l|}{1978} \\
\hline 1979 & Amendment - Industrial Conciliation Act \\
\hline \multicolumn{2}{|l|}{1980} \\
\hline 1981 & Amendment - Industrial Conciliation Act; Court reinstates dismissed workers \\
\hline \multicolumn{2}{|l|}{1982} \\
\hline \multicolumn{2}{|l|}{1983} \\
\hline \multicolumn{2}{|l|}{1984} \\
\hline \multicolumn{2}{|l|}{1985} \\
\hline 1986 & Abolition of Influx Control Act \\
\hline \multicolumn{2}{|l|}{1987} \\
\hline 1988 & Amendment - Industrial Conciliation Act \\
\hline \multicolumn{2}{|l|}{1989} \\
\hline \multicolumn{2}{|l|}{1990} \\
\hline 1991 & Laboria Minute \\
\hline 1992 & Labour Relations Act \\
\hline 1993 & Agricultural Labour Act 1993; Public Service Labour Relations Act 1993 \\
\hline \multicolumn{2}{|l|}{1994} \\
\hline 1995 & New Labour Relations Act 1995 \\
\hline 1996 & Amendment - Labour Relations Act 1996 and Proclamation Act 1996 \\
\hline 1997 & Basic Conditions of Employment Act 1997 \\
\hline 1998 & Amendment - Labour Relations Act 1998 \\
\hline 1999 & Skills Development Act 1999 \\
\hline 2000 & Amendment - Labour Relations Act 2000 \\
\hline \multicolumn{2}{|l|}{2001} \\
\hline 2002 & Amendment - Labour Relations Act 2002 \\
\hline $2003-2006$ & No significant developments \\
\hline
\end{tabular}

Source: Authors' own compilation from various sources

\subsubsection{Diagnostic tests}

Stationarity tests were conducted on all the said variables and it was found that all the variables were I(1). Second-order testing indicated that no serious autocorrelation, heteroscedasticity and mulitcollinearity were present. The residuals were normally distributed (See appendix A). 
Table 2

Stationarity test results for the Augmented Dickey-Fuller test (Phillips-Perron in brackets)

\begin{tabular}{|l|l|c|c|}
\hline \multicolumn{1}{|c|}{ Variable } & \multicolumn{1}{|c|}{ Trend, intercept, none } & \multicolumn{1}{c|}{ Level } & \multicolumn{1}{c|}{$\mathbf{1}^{\text {st }}$ difference } \\
\hline Capital output & Intercept & $-2.54(-2.51)$ & $-4.68^{*}\left(-4.67^{*}\right)$ \\
\hline Labour share & Trend and intercept & $-2.58(-2.39)$ & $-6.07^{*}\left(-8.08^{*}\right)$ \\
\hline Strikes & None & $-1.31(-1.17)$ & $-5.82^{*}\left(-5.87^{*}\right)$ \\
\hline Real interest rate & None & $-1.91(-1.007)$ & $-4.79^{*}\left(-5.76^{*}\right)$ \\
\hline
\end{tabular}

* Rejection of the 5 per cent critical value $\left(\mathrm{H}_{\mathrm{o}}\right.$ : variable contains a unit root)

\subsubsection{Estimation of the model}

Sequential ad hoc estimation was conducted on the function adding all the lags, for example, adding lag 1 to 7 for labour share. This ad hoc estimation suffers from problems such as no a priori guide as to what the maximum lag should be and it also causes fewer degrees of freedom left, which compromises statistical inference, especially in this case, since annual data were used. In addition, successive lags tend to be highly correlated causing higher standard errors in relation to the estimation. (Gujarati \& Porter, 2008). The lag structure was therefore based upon prior theoretical considerations as well as documented experiences of businesses' decisiontaking periods, which resulted in the lags as set out in the function.

A variety of theoretical literature exists to explain discontinuities and discrete adjustment in economics. See for instance Hamermesh (1989), Blinder (1981), Bernanke (1983), Pindyck (1991), Dixit (1992), Caballero and Engel (1992) as well as the work of Cross (1994).

Uncertainty about labour as a production factor and institutional friction and cost are the main theoretical reasons for the long lag of the labour share effect on the capital/ output ratio. Beliefs based on non-economic factors like mistrust, are the reason why the transmission becomes significant after a long period. (Blanchard \& Phillipon, 2006). When technology becomes available it is implemented as soon as it is profitable to introduce, even if shocks had taken place a long time before and should already have been worked out and adjustment seems to have nothing to do with the original shock.
The outcome of appropriability depends on the respective supply of elasticities of labour and capital, the degree to which they need each other in production and the institutional buildup in favour of labour. The low elasticity of capital in the short run makes it possible for labour to appropriate capital in the short run (growth of the labour share in production at the expense of capital) through the institutional buildup in favour of labour. Capital is however much more flexible in the long run and will develop new, less labour-intensive technologies that will guarantee capital returns equivalent to what capital can get elsewhere in the world. Investment and unemployment will increase over the longer run (Caballero \& Hammour, 1997).

The cost in this inefficient allocation of labour and capital will be borne by labour in the form of a decrease in labour share or change in capital share and greater unemployment in favour of a recovery in capital profitability in the long run.

The lag in the effect of appropriation on capital depends on the endogenous nature and therefore the elasticity of supply and demand of capital intensive technologies. The latter is also influenced by the profitability and service life of existing capital as well as investment incentives (Caballero \& Hammour, 1997). The relatively long lag between the increase in appropriation (labour share) and the decrease in profits and deepening of capital (capital/output ratio) can be explained as the result of the time taken to develop capital intensive technologies and the cost of substituting labour for capital. The inelasticity seems to lead to responses to shocks of up to 19 years in France (Caballero \& Hammour, 1997: 5-7; 14 and 21). In a developing 
country such as Argentina the lag is much shorter because capital intensive technologies had already existed in Europe and because of globalisation it took less time to implement. This makes it easier and cheaper to substitute labour for capital (Caballero \& Hammour, 1997: 22). The experiences of emerging market countries like Argentina formed the theoretical foundation for the chosen lag length of seven years of the labour share variable.

In the short run the reaction after strikes and other shocks is more severe in labour markets characterised by bad labour relations and mistrust. The effects of these shocks, exogenous and endogenous, are also of a long run nature (Blanchard \& Phillipon, 2006: 21-22).

A recent case study of a leading retail company indicates that the real cost of strikes and other shocks take around two years to formally work through the management activities of companies (ER Report, 2010). The company faced significant strike action from 17 September 2008 until 20 October 2008. However, the last award by the CCMA stemming from the strike activity and the response of the company was only made in April 2010 (ER Report, 2010).

This market experience informed the chosen lag length of the strikes variable in the analysis. Increase in actual unemployment as a response to strikes and other shocks, for example HIV/ AIDS, are reflected in the capital/output ratio data after approximately two years. The short run effect on the capital/output ratio is due to the initial increase in unemployment and resulted increase in capital's share of production. The period of two years in terms of the decision-making processes of businesses was also used as a benchmark for the chosen lag length of the institutional dummy variable.

The two year benchmark also informed the lag length of the real interest rate variable. The period of five years is based on the difference in the time period from employer's decision to substitute labour with capital and the seven years it takes for this capital deepening to become visible. Theoretically, this makes the cost of capital relevant after a period of approximately five years.

Furthermore, specific attention was given to the lag length to be employed for the HIV/ AIDS variable. The literature suggests that the information about the rate at which the HIV/AIDS epidemic is developing is relatively plausible. However, information on the rate at which the epidemic is destroying the economic and development potential of the economy is not sufficient. This leads to substantial uncertainty about the macroeconomic impact of HIV/ AIDS on the South African economy (Booysen, Geldenhuys \& Marinkov, 2003: 11-12).

Terwin (2004: 1) conducted the largest survey on the impact of HIV/AIDS on business in South Africa up to that point. The results show that 34 per cent of the 1006 participating companies reported that HIV/AIDS has already had a depressing effect on profit levels. Moreover, more than half expected an adverse impact on profitability within a five year framework (Terwin, 2004: 1). A lag length of three years for the HIV/AIDS dummy was used as a benchmark for the economic cost of the epidemic to manifest itself.

The estimation of the model yielded the following results as summarised in Table 3

Table 3

Regression results

\begin{tabular}{|c|c|c|c|c|}
\hline \multicolumn{5}{|c|}{ Dependent variable: capital output } \\
\hline \multicolumn{5}{|c|}{ Method: least squares } \\
\hline \multicolumn{5}{|c|}{ Sample (adjusted): 1977-2004 } \\
\hline & Coefficient & Std. error & t-statistic & Prob. \\
\hline C & 3.794711 & 0.481619 & 7.879081 & 0.0000 \\
\hline LS(-7) & -2.453351 & 0.855084 & -2.869135 & 0.0089 \\
\hline
\end{tabular}




\begin{tabular}{|l|c|c|c|c|}
\hline STRIKES(-2) & 0.000288 & $4.27 \mathrm{E}-05$ & 6.745689 & 0.0000 \\
\hline RR(-5) & -0.018075 & 0.003943 & -4.584490 & 0.0001 \\
\hline DUM(-2) & -0.168158 & 0.050066 & -3.358737 & 0.0028 \\
\hline AIDS(-3) & 0.049897 & 0.041720 & 1.196010 & 0.2444 \\
\hline R-squared & 0.766176 & Mean dependent var & 2.492857 \\
\hline Adjusted R-squared & 0.713035 & S.D. dependent var & 0.143833 \\
\hline S.E. of regression & 0.077050 & Akaike info criterion & -2.101317 \\
\hline Sum squared resid & 0.130607 & Schwarz criterion & -1.815845 \\
\hline Log likelihood & 35.41844 & Hannan-Quinn criter. & -2.014046 \\
\hline F-statistic & 14.41761 & Durbin-Watson stat & 1.875051 \\
\hline Prob (F-statistic) & 0.000003 & & \\
\hline
\end{tabular}

Source: Eviews estimates

All the explanatory variables are statistically significant at the 95 per cent confidence level, except the HIV/AIDS prevalence dummy which is significant at the 75 per cent confidence level. The distributional conflict variable, labour share (LS in equation output), has a negative relationship with the capital/output ratio which is lagged with 7 periods, the coefficient is relatively large. This signifies that capital is crowded out by labour wage demands. The effect is therefore even worse than the findings of both Caballero and Hammour (1997) and Blanchard and Phillipon (2006). It may indicate that businesses cannot effectively hedge themselves against bad labour relations by simply making use of more capital intensive technology. It can also be an indication that skills shortages had a detrimental effect on production in South Africa much earlier than previously anticipated.

The relational conflict variable, frequency of strikes, has a positive relationship to the capital/ output ratio and it is significant after two years. The small but highly significant coefficient is an indication that the hedging of uncertain labour by using more capital intensive methods has been largely completed. This implies that as the frequency of strikes becomes higher the switch to capital is more likely, with the possible secondary effect of higher levels of unemployment.

The institutional dummy variable is also significant after two years and it has a negative relationship to the capital/output ratio. This implies that when there is intervention by institutions in favour of labour the capital/ output ratio decline. Contrary to the finding of Caballero and Hammour (1997) the regulation of the labour markets in South Africa, in fact increases employment. This finding corresponds with the conclusion of Blanchard and Phillipon (2006) that regulating as such does not create unemployment. Labour regulation after 1973 in favour of labour seems to create certainty in the labour market as a whole. Labour regulation as such does not seem to be the reason for the substitution of labour for capital.

The real interest rate has a negative relationship to the capital/output ratio over a long period of 5 years. The finding corresponds with that of Caballero and Hammour (1997) and Blanchard and Phillipon's (2006) view on the inflexibility of capital intensive technology.

The HIV/AIDS prevalence dummy is not as significant as expected; though it has the correct sign, indicating that as HIV/AIDS prevalence increases the capital/output ratio will also increase. This could indicate that the switch to capital is driven rather by conflict variables, and not the fear of high labour turnover due to AIDS deaths. It can also be that the earlier shift to capital intensive production already makes the influence of HIV/AIDS less visible. Therefore uncertainty on the labour market was already hedged but for reasons other than HIV/AIDS. 
From the magnitude of the coefficients it can be said that the distributional conflict variable and the institutional dummy variable have the largest impact on the capital/output ratio. The adjusted $\mathrm{R}^{2}$ indicates that 71 per cent of the capital/output ratio is due to the explanatory variables and the F-statistic $(p=0)$ indicates that the capital/output ratio jointly is significantly explained by all the explanatory variables.

\subsection{Co-integration analysis}

Since the variables are integrated to the same order, cointegration analysis can be conducted to establish if a long-run equilibrium relationship exists between the variables in the model and to rule out the possibility of spurious regression. The Schwarz information criteria (SIC) and the Hannan-Quinn information criterion (HQ) indicated that the optimal lag structure is $1 \mathrm{lag}$ (up to 4 lags were tested), this is appropriate, since annual data are analysed and a longer lag structure will create problems in motivating cointegration. The results are presented in the table below. One cointegrating relationship as indicated by the Trace and Maximum Eigenvalue test statistics was present. This implies a longrun equilibrium relationship between the variables and therefore the short-run dynamics can be analysed by using the Vector Error correction model (VECM).

Table 4

Cointegration results

\begin{tabular}{|c|c|c|c|c|}
\hline \multicolumn{5}{|c|}{ Unrestricted cointegration rank test (Trace) } \\
\hline $\begin{array}{l}\text { Hypothesised } \\
\text { no. of } C E(s)\end{array}$ & Eigenvalue & $\begin{array}{l}\text { Trace } \\
\text { statistic }\end{array}$ & $\begin{array}{l}0.05 \\
\text { Critical value }\end{array}$ & Prob.** \\
\hline None * & 0.572871 & 55.59030 & 47.85613 & 0.0079 \\
\hline At most 1 & 0.410458 & 27.51825 & 29.79707 & 0.0896 \\
\hline At most 2 & 0.238845 & 10.08072 & 15.49471 & 0.2746 \\
\hline At most 3 & 0.032034 & 1.074434 & 3.841466 & 0.2999 \\
\hline \multicolumn{5}{|c|}{$\begin{array}{l}\text { Trace test indicates } 1 \text { cointegrating eqn(s) at the } 0.05 \text { level } \\
* \text { denotes rejection of the hypothesis at the } 0.05 \text { level } \\
*^{*} \text { MacKinnon-Haug-Michelis (1999) p-values }\end{array}$} \\
\hline \multicolumn{5}{|c|}{ Unrestricted cointegration rank test (maximum eigenvalue) } \\
\hline $\begin{array}{l}\text { Hypothesised } \\
\text { no. of CE(s) }\end{array}$ & Eigenvalue & $\begin{array}{l}\text { Max-Eigen } \\
\text { statistic }\end{array}$ & $\begin{array}{l}0.05 \\
\text { Critical value }\end{array}$ & Prob.** \\
\hline None ${ }^{*}$ & 0.572871 & 28.07205 & 27.58434 & 0.0433 \\
\hline At most 1 & 0.410458 & 17.43753 & 21.13162 & 0.1523 \\
\hline At most 2 & 0.238845 & 9.006284 & 14.26460 & 0.2856 \\
\hline At most 3 & 0.032034 & 1.074434 & 3.841466 & 0.2999 \\
\hline \multicolumn{5}{|c|}{$\begin{array}{l}\text { Max-Eigenvalue test indicates } 1 \text { cointegrating eqn(s) at the } 0.05 \text { level } \\
* \text { denotes rejection of the hypothesis at the } 0.05 \text { level } \\
* * \text { MacKinnon-Haug-Michelis (1999) p-values }\end{array}$} \\
\hline
\end{tabular}

Source: Eviews estimates 
Table 5

Vector error correction results

\begin{tabular}{|l|c|c|c|c|}
\hline Error correction: & $\mathrm{D}(\mathrm{CO})$ & $\mathrm{D}(\mathrm{STRIKES})$ & $\mathrm{D}(\mathrm{LS})$ & $\mathrm{D}(\mathrm{RR})$ \\
\cline { 2 - 5 } cointegrating equation & 0.017945 & 82.28092 & $\mathbf{- 0 . 0 0 8 2 7 5}$ & $\mathbf{- 1 . 1 5 2 3 1 3}$ \\
& $(0.01282)$ & $(43.3332)$ & $(0.00278)$ & $(0.51809)$ \\
& {$[1.39990]$} & {$[1.89879]$} & {$[-2.97234]$} & {$[-2.22416]$} \\
\hline
\end{tabular}

Source: Eviews estimate; t-statistics in [ ]

The adjustment coefficients are shown in Table 4. The small and insignificant coefficient of capital output $(\mathrm{CO})$ indicates that it is weakly exogenous. The as (highlighted) in Table 4 show that the labour share (LS) and the real rate (RR) enter the cointegrating equation significantly and it adjusts to equilibrium, since the coefficients are negative (meeting the stability condition). In the case of the labour share, adjustment towards equilibrium will be slow and moderate to quick for interest rates. The frequency of strikes' coefficient is significant on a 90 per cent level and would move away from equilibrium (positive coefficient). Since not all the variables comply with the stability condition it implies that equilibrium might not be reached or take a very long time to return to equilibrium after a shock.

The weak exogenous nature of capital output confirms that capital investment is not to be the overall result of sound economic decision making. Non-economic factors, like militancy, seem to play a cardinal role in investment decisions. Strikes seem to change long run investment behaviour, making capital a permanent rather than a cyclical substitute for labour. Militancy also nullified the positive effects of a regulated framework for the labour market.

This was confirmed by the impulse response function of generalised impulses (ordering not important) from Figure 1 below. Capital output (CO) reacts to strikes (first diagram) and moves away from equilibrium; capital output reacts to the labour share (LS) (second diagram) and moves towards equilibrium but at a very slow rate and capital output reacts to the real rate (RR) and moves back towards equilibrium rather quickly. This confirms results from previous studies that once labour is replaced by capital, reversal in the foreseeable future is not likely.

\section{Figure 1}

Impulse response function for capital output (CO)

Response to Cholesky One S.D. Innovations Response of CO to STRIKES

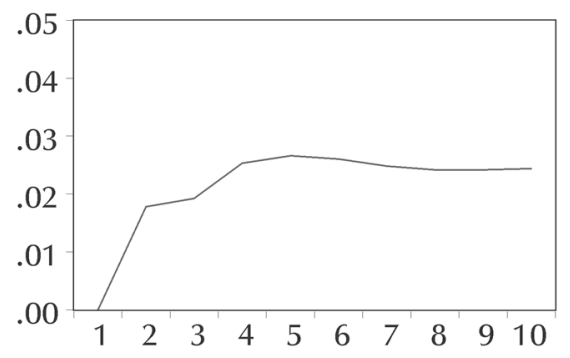

Response of CO to LS
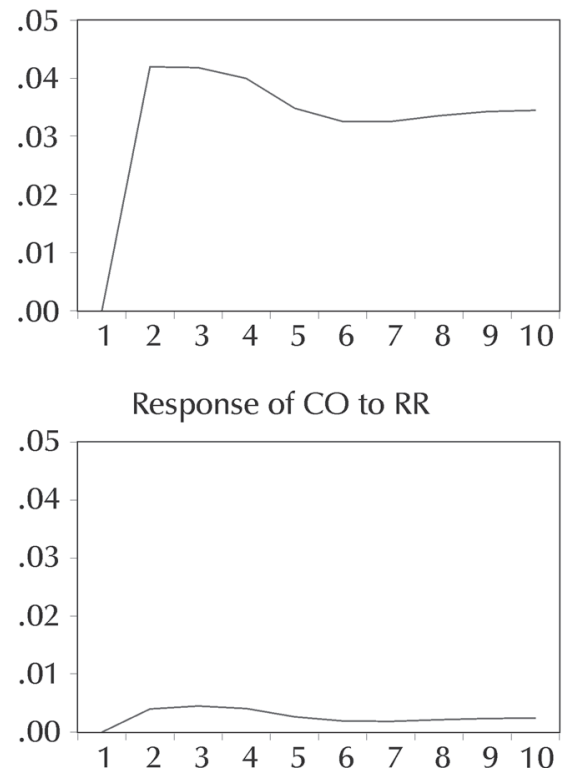

Source: Eviews estimation 
5

\section{Conclusions}

The objective of this paper was to analyse the role labour conflict played in the persistence of underemployment in South Africa. The long period of economic growth, relatively low interest rates, low inflation and positive business sentiment in South Africa are not reflected in job creation. Arguments for the persistence of unemployment are based on the progressive growth in labour supply, the change in the nature of the demand for labour and a lack of growth in South Africa. The argument in this paper is that there is something structurally wrong with an economy and labour market that for a period of 20 years or longer cannot absorb and allocate surplus labour but instead moves to more capital-intensive modes of production, whether it is the result of frictions in the pricing mechanism or more fundamental reasons. The paper's contribution to the debate on unemployment is to focus on labour conflict as a contributor to the persistence of underemployment in South Africa.

The role played by labour conflict in the persistence of underemployment in South Africa was analysed with the help of two models. Labour conflict in these models originates both from an over-regulated labour market, where labour appropriates capital, and from bad labour relations. In both models a switch in technology is the channel through which underemployment results. The frequency of strikes was used as a proxy for the relational conflict variable (BP model) and the compensation of employees to gross value added ratio was used as a proxy for the distributional conflict variable to represent labour share ( $\mathrm{CH}$ model). These variables were used in conjunction with a dummy variable for intervention by institutions in favour of labour. The real interest rate and the HIV/ AIDS prevalence dummy were used as control variables for possible specification bias.

It was found that capital is crowded out by labour wage demands. Bad labour relations cannot be efficiently hedged by more capital intensive technology. Also skills shortages already at an early stage had a detrimental effect on production in South Africa.
A significant positive relationship between the relational conflict variable, frequencies of strikes, with the capital/output ratio was observed. This implies that as the frequency of strikes becomes higher the switch to capital is more likely. The small but highly significant coefficient is an indication that the hedging of uncertain labour by using more capital intensive methods has been completed. Bad labour relations contribute to the continued use of capital-intensive technology in South Africa and therefore play a role in explaining unemployment.

The significant results from the institutional dummy variable implies that when there is intervention by institutions in favour of labour the capital/output ratio declines. The regulation of the labour markets in South Africa as such, does not create unemployment, but relatively high and stable underemployment of labour in relation to capital. The high and persistent levels of unemployment are rather the result of bad labour relations. This finding corresponds with that of Blanchard \& Phillipon (2006).

The real interest rate has a negative relationship to the capital/output ratio over a long period of 5 years. The finding confirms the views of both the Caballero and Hammour $(\mathrm{CH})$ and Blanchard and Phillipon (BP) model on the inflexibility of capital intensive technology. The results indicate that as HIV/AIDS prevalence increases, the capital/output ratio will also increase. This variable was not as significant as expected and it seems that uncertainty in the labour market was already hedged but for reasons other than HIV/AIDS.

The cointegration analysis confirms results from previous studies that once labour is replaced by capital, reversal in the foreseeable future is not likely. It is therefore very doubtful whether the situation can be reversed in the near future due to the highly inelastic short-run and inflexible long-run nature of capital and the historical and social nature of conflict in the labour market.

No automatic economic mechanism exists to rectify the remanence in underemployment because the factors underlying underemployment are of a historical, political and social nature. Classical employment policies cannot remedy the 
historical and endemic nature of labour market conflict and remanence in underemployment in South Africa. Classical employment policies of low interest rates and high output growth to create jobs will probably contribute only to cyclical employment or could even give business the leverage to intensify the use of capital in production, at the cost of low skilled labour. It therefore seems that the presence and nature of conflict do not contribute to the welfare of labour - not even in the short run - but seem instead to counter the government's efforts (regulation) to improve the wellbeing of labour as a production factor.

\section{Acknowledgement}

*The authors appreciate the valuable comments from two anonymous referees and the editor on a previous version. The usual disclaimer applies.

\section{References}

BARKER, F. 2007. The South African labour market, ( $5^{\text {th }}$ ed.) Van Schaik: Pretoria.

BERNANKE, B.S. 1983. Irreversibility, uncertainty, and cyclical investment, Quarterly Journal of

Economics, 98: 85-106.

BHORAT, H. 2004. Labour market challenges in the post-apartheid South Africa, South African Journal of Economics, 72(5): 940-977.

BHORAT, H. \& HODGE, J. 1999. Decomposing shifts in labour demand in South Africa, South African Journal of Economics, 67(3): 348-380.

BHORAT, H. \& VAN DER WESTHUIZEN, C. 2009. A synthesis of current issues in the labour regulatory environment, Development Policy Research Unit, Working Paper 09/135, University of Cape Town. BLANCHARD, O. \& PHILLIPON, T. 2006. The quality of labour relations and unemployment, MIT, NYU and NBER, Working paper, November.

BLINDER, A.S. 1981. Retail inventory behavior and aggregate fluctuations. Brookings Papers on Economic Activity, 2: 443-505.

BOOYSEN, F. le R., GELDENHUYS, J.P. \& MARINKOV, M. 2003. The impact of HIV/AIDS on the South African economy: a review of current evidence, paper prepared for TIPS/DPRU conference on 'The challenge of growth and poverty: the South African economy since democracy' 8-10 September 2003, Indaba Hotel, Johannesburg.

BOWLES, S. \& GINTIS, H. 1990. Contested exchange: new micro foundations for the political economy of capitalism, Journal of Politics and Society, 18: $165-222$.

CABALLERO, R.J. \& ENGEL, E.M.R.A. 1992.

Microeconomic adjustment hazards and aggregate dynamics, NBER Working Paper No. 4090.

CABALLERO, R.J. \& HAMMOUR, M.L. 1997. Jobless growth: appropriability, factor substitution and unemployment, NBER Working Paper No. 6221, October.

CROSS, R. 1994. The macroeconomic consequences of discontinuous adjustment: selective memory of non-dominated extrema, Scottish Journal of Political Economy, 41(2): 212-221.

DIXIT, A. 1992. Investment and hysteresis. Journal of Economic Perspectives, 6(1): 107-132.

EMPLOYMENT RELATIONS REPORT. 2010.

Employment relations report, April 2010, Woolworths South Africa: Cape Town.

FICK, R. \& HIGH, S.H. 1987. The theory and practice of industrial relations in South Africa, Hodder \&

Stoughton: Bergvlei.

FRIEDMAN, M. 1968. The role of the monetary policy, American Economic Review, 58(1): 1-17. GUJARATI, D.N. \& PORTER, D.C. 2010. Basic econometrics (5th ed.) McGraw-Hill. GUPTA, R. \& DU TOIT, C.B. 2009. Active versus passive policies of unemployment: growth and public finance perspectives, South African Journal of Economic \& Management Sciences, 12(1): 1-10.

HAMERMESH, D.S. 1989. Labor demand and the structure of labor cost, American Economic Review, 79(4): 674-689.

HICKS, J. 1974. The crisis in Keynesian economics, Basil-Blackwell: Oxford.

HOFMEYR, J. 1994. Reform of the labour market in South Africa, South African Journal of Economic History, 9(1): 13-30.

JONES, S. \& INGGS, J. 1994. An overview of the South African economy in the 1980s, South African Journal of Economic History, 9(2): 1-18.

KINGDON, G. \& KNIGHT, J. 2001a. What have we learnt about unemployment from microdatasets in South Africa? Centre for the study of African economies, Department of Economics, Oxford University. KINGDON, G.G. \& KNIGHT, J. 2001b. Why high open unemployment and small informal sector in South Africa? Centre for the study of African economies, Department of Economics, Oxford University.

LAYARD, R., NICKELL, S. \& JACKMAN, R. 1991. Unemployment: macroeconomic performance and the labor market, Oxford University Press: Oxford. MCCARTHY, C. 2005. Productivity, performance in developing countries. country case studies: South 
Africa. Paper presented to the Secretariat of the United Nations Industrial Development Organization, November 2005.

PINDYCK, R.S. 1991. Irreversibility, uncertainty, and investment, Journal of Economic Literature, 26(3): $1110-1148$.

ROGERS, C. 1989. Money, interest and capital, Cambridge University Press: Cambridge. SCHOEMAN, C., BLAAUW, P.F. \& PRETORIUS,

A.M. 2008. An investigation into the determinants of the South African unemployment rate, 1970-2002, Acta Academica, 40(3): 67-84.

SCHOEMAN, C. \& BLAAUW, P.F. 2007.

Unemployment in South Africa 1970-2002: A configuration concern for future employment, Paper presented at the Annual Conference of the Scottish Economic Society, 2-4 April 2007, Perth, Scotland. SKOTT, P. 1991. Efficiency wages, mark-up pricing and effective demand in The Economics of the Restructuring and Intervention, Michie, J. (ed.) Edward Elgar: Aldershot.

SLABBERT, K. 1999. The future role of trade unions in South Africa, Aambeeld, November 1999, published by the Rand Afrikaans University, Johannesburg, South Africa.
TERWIN, J.E. 2004. The impact of HIV/AIDS on business in South Africa - a survey conducted by the Bureau for Economic Research (BER), funded by South African Business Coalition on HIV \& AIDS (SABCOHA), Paper presented at the International Conference on AIDS, 11-16 July 2004, Bangkok, Thailand.

UNAIDS/WHO 2006. Report on the global AIDS Epidemic 2006, UNAIDS/WHO: New York, http:// www.unaids.org/en/KnowledgeCentre/HIVData/ GlobalReport/2008/.

VAN DER VELDEN, S. 2009. Data on frequency of strikes in South Africa, received via e-mail in Microsoft Office Excel, June 2009.

VAN DER VELDEN, S. \& VISSER, W. 2006. Strikes in the Netherlands and South Africa, 1990-1998: a comparison, The South African Journal of Labour Relations, 30(1): 51-75.

VAN DIJK, M. 2003. South African manufacturing performance in international perspective 1970-1999, The South African Journal of Economics, 71(1): 119-142. 


\section{Appendix A}

\begin{tabular}{|c|c|c|c|c|}
\hline \multicolumn{5}{|c|}{ Heteroskedasticity test: White } \\
\hline F-statistic & 0.705571 & \multicolumn{2}{|c|}{ Prob. $F(16,11)$} & 0.7446 \\
\hline Obs*R-squared & 14.18161 & \multicolumn{2}{|c|}{ Prob. Chi-square(16) } & 0.5852 \\
\hline Scaled explained SS & 10.73566 & \multicolumn{2}{|c|}{ Prob. Chi-square(16) } & 0.8255 \\
\hline \multicolumn{5}{|l|}{ Test equation: } \\
\hline \multicolumn{5}{|c|}{ Dependent variable: $\mathrm{RESID}^{\wedge} 2$} \\
\hline \multicolumn{5}{|c|}{ Method: least squares } \\
\hline \multicolumn{5}{|c|}{ Date: 03/12/10 Time: 10:58 } \\
\hline \multicolumn{5}{|c|}{ Sample: 19772004} \\
\hline \multicolumn{5}{|c|}{ Included observations: 28} \\
\hline \multicolumn{5}{|c|}{ Collinear test regressors dropped from specification } \\
\hline Variable & Coefficient & Std. error & t-statistic & Prob. \\
\hline $\mathrm{C}$ & -0.501645 & 1.658249 & -0.302515 & 0.7679 \\
\hline $\mathrm{LS}(-7)$ & 2.328121 & 5.930229 & 0.392585 & 0.7021 \\
\hline $\operatorname{LS}(-7)^{\wedge} 2$ & -2.490345 & 5.303488 & -0.469567 & 0.6478 \\
\hline LS(-7)*STRIKES(-2) & 0.001052 & 0.000652 & 1.611888 & 0.1353 \\
\hline $\mathrm{LS}(-7) * \mathrm{RR}(-5)$ & 0.032893 & 0.056471 & 0.582475 & 0.5720 \\
\hline $\operatorname{LS}(-7) * \operatorname{DUM}(-2)$ & -0.071710 & 0.038966 & -1.840349 & 0.0928 \\
\hline LS(-7)*AIDS(-3) & -0.195869 & 0.824637 & -0.237521 & 0.8166 \\
\hline STRIKES(-2) & -0.000610 & 0.000363 & -1.683599 & 0.1204 \\
\hline $\operatorname{STRIKES}(-2) \wedge 2$ & $-2.74 \mathrm{E}-09$ & 3.07E-08 & -0.089234 & 0.9305 \\
\hline STRIKES(-2)*RR(-5) & $-2.08 \mathrm{E}-06$ & $2.22 \mathrm{E}-06$ & -0.937032 & 0.3689 \\
\hline STRIKES(-2)*DUM(-2) & $-6.39 \mathrm{E}-05$ & 0.000100 & -0.638058 & 0.5365 \\
\hline STRIKES(-2)*AIDS(-3) & $3.83 \mathrm{E}-05$ & $2.40 \mathrm{E}-05$ & 1.597031 & 0.1386 \\
\hline $\operatorname{RR}(-5)$ & -0.016356 & 0.031728 & -0.515504 & 0.6164 \\
\hline $\operatorname{RR}(-5) \wedge 2$ & -0.000155 & 0.000153 & -1.008106 & 0.3351 \\
\hline $\mathrm{RR}(-5) * \mathrm{DUM}(-2)$ & 0.017746 & 0.020198 & 0.878599 & 0.3984 \\
\hline $\mathrm{RR}(-5) * \operatorname{AIDS}(-3)$ & 0.001057 & 0.002884 & 0.366594 & 0.7209 \\
\hline $\operatorname{AIDS}(-3)$ & 0.078474 & 0.466070 & 0.168373 & 0.8693 \\
\hline R-squared & 0.506486 & \multicolumn{2}{|c|}{ Mean dependent var } & 0.004665 \\
\hline Adjusted R-squared & -0.211353 & \multicolumn{2}{|c|}{ S.D. dependent var } & 0.007439 \\
\hline S.E. of regression & 0.008187 & \multicolumn{2}{|c|}{ Akaike info criterion } & -6.492476 \\
\hline Sum squared resid & 0.000737 & \multicolumn{2}{|c|}{ Schwarz criterion } & -5.683638 \\
\hline Log likelihood & 107.8947 & \multicolumn{2}{|c|}{ Hannan-Quinn criter. } & -6.245207 \\
\hline F-statistic & 0.705571 & \multirow{2}{*}{\multicolumn{2}{|c|}{ Durbin-Watson stat }} & 2.559559 \\
\hline Prob(F-statistic) & 0.744593 & & & \\
\hline
\end{tabular}




\begin{tabular}{|c|c|c|c|c|}
\hline \multicolumn{5}{|c|}{ Breusch-Godfrey serial correlation LM test: } \\
\hline F-statistic & 0.057647 & \multicolumn{2}{|c|}{ Prob. $F(2,20)$} & 0.9441 \\
\hline Obs*R-squared & 0.160486 & \multicolumn{2}{|c|}{ Prob. Chi-square(2) } & 0.9229 \\
\hline \multicolumn{5}{|l|}{ Test equation: } \\
\hline \multicolumn{5}{|c|}{ Dependent variable: RESID } \\
\hline \multicolumn{5}{|c|}{ Method: least squares } \\
\hline \multicolumn{5}{|c|}{ Date: 03/12/10 Time: 10:59 } \\
\hline \multicolumn{5}{|c|}{ Sample: 19772004} \\
\hline \multicolumn{5}{|c|}{ Included observations: 28} \\
\hline \multicolumn{5}{|c|}{ Presample missing value lagged residuals set to zero. } \\
\hline Variable & Coefficient & Std. error & t-statistic & Prob. \\
\hline $\mathrm{C}$ & 0.034116 & 0.519016 & 0.065732 & 0.9482 \\
\hline LS $(-7)$ & -0.063983 & 0.923474 & -0.069285 & 0.9455 \\
\hline STRIKES(-2) & $5.41 \mathrm{E}-06$ & $4.79 \mathrm{E}-05$ & 0.112942 & 0.9112 \\
\hline $\mathrm{RR}(-5)$ & -0.000199 & 0.004181 & -0.047537 & 0.9626 \\
\hline $\operatorname{DUM}(-2)$ & -0.001931 & 0.061843 & -0.031231 & 0.9754 \\
\hline $\operatorname{AIDS}(-3)$ & 0.000807 & 0.043962 & 0.018367 & 0.9855 \\
\hline RESID $(-1)$ & -0.010814 & 0.273876 & -0.039484 & 0.9689 \\
\hline RESID(-2) & -0.084035 & 0.248758 & -0.337819 & 0.7390 \\
\hline R-squared & 0.005732 & \multicolumn{2}{|c|}{ Mean dependent var } & $-1.02 \mathrm{E}-16$ \\
\hline Adjusted R-squared & -0.342262 & \multicolumn{2}{|c|}{ S.D. dependent var } & 0.069551 \\
\hline S.E. of regression & 0.080579 & \multicolumn{2}{|c|}{ Akaike info criterion } & -1.964208 \\
\hline Sum squared resid & 0.129859 & \multicolumn{2}{|c|}{ Schwarz criterion } & -1.583578 \\
\hline Log likelihood & 35.49892 & \multicolumn{2}{|c|}{ Hannan-Quinn criter. } & -1.847846 \\
\hline F-statistic & 0.016470 & \multirow{2}{*}{\multicolumn{2}{|c|}{ Durbin-Watson stat }} & 1.903100 \\
\hline Prob(F-statistic) & 0.999994 & & & \\
\hline
\end{tabular}




\section{Correlation matrix}

\begin{tabular}{|l|l|l|l|}
\hline \multicolumn{1}{|c|}{ CO } & \multicolumn{1}{|c|}{ STRIKES } & \multicolumn{1}{c|}{ LS } & \multicolumn{1}{c|}{ RR } \\
\hline 1 & 0.6235009313112387 & -0.04670670492374031 & 0.2531346970598506 \\
\hline 0.6235009313112387 & 1 & 0.1369744889818502 & 0.06673009173871417 \\
\hline-0.04670670492374031 & 0.1369744889818502 & 1 & -0.1987465169268578 \\
\hline 0.2531346970598506 & 0.06673009173871417 & -0.1987465169268578 & 1 \\
\hline
\end{tabular}

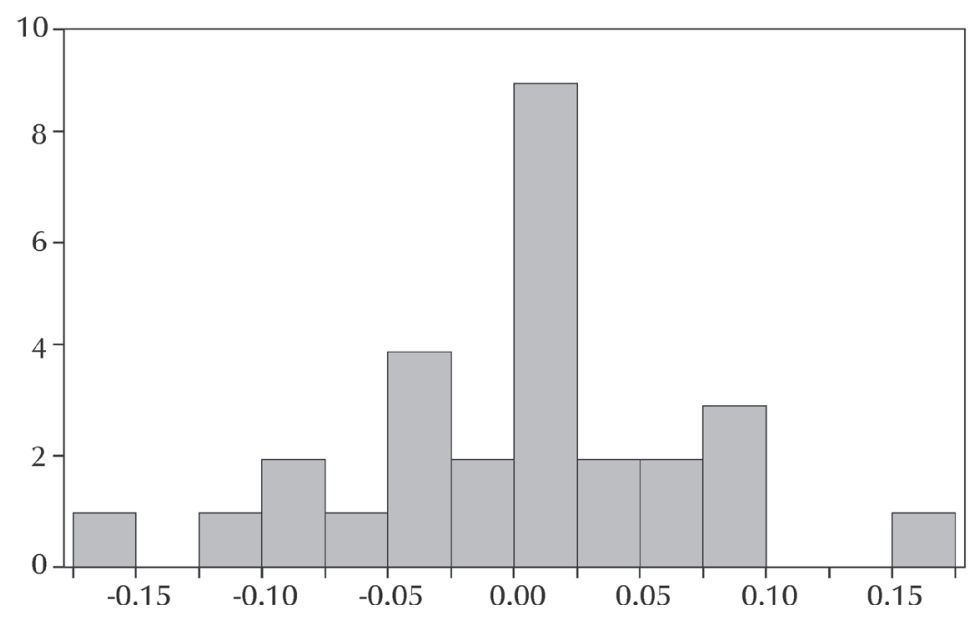

Series: Residuals Sample 19772004

Observations 28

$\begin{array}{lc}\text { Mean } & -1.02 \mathrm{e}-16 \\ \text { Median } & 0.005632 \\ \text { Maximum } & 0.162687 \\ \text { Minimum } & -0.172197 \\ \text { Std. Dev. } & 0.069551 \\ \text { Skewness } & -0.156741 \\ \text { Kurtosis } & 3.452472 \\ & \\ \text { Jarque-Bera } & 0.353502 \\ \text { Probability } & 0.837988\end{array}$


Response to generalised one S.D. Innovations Response of CO to STRIKES
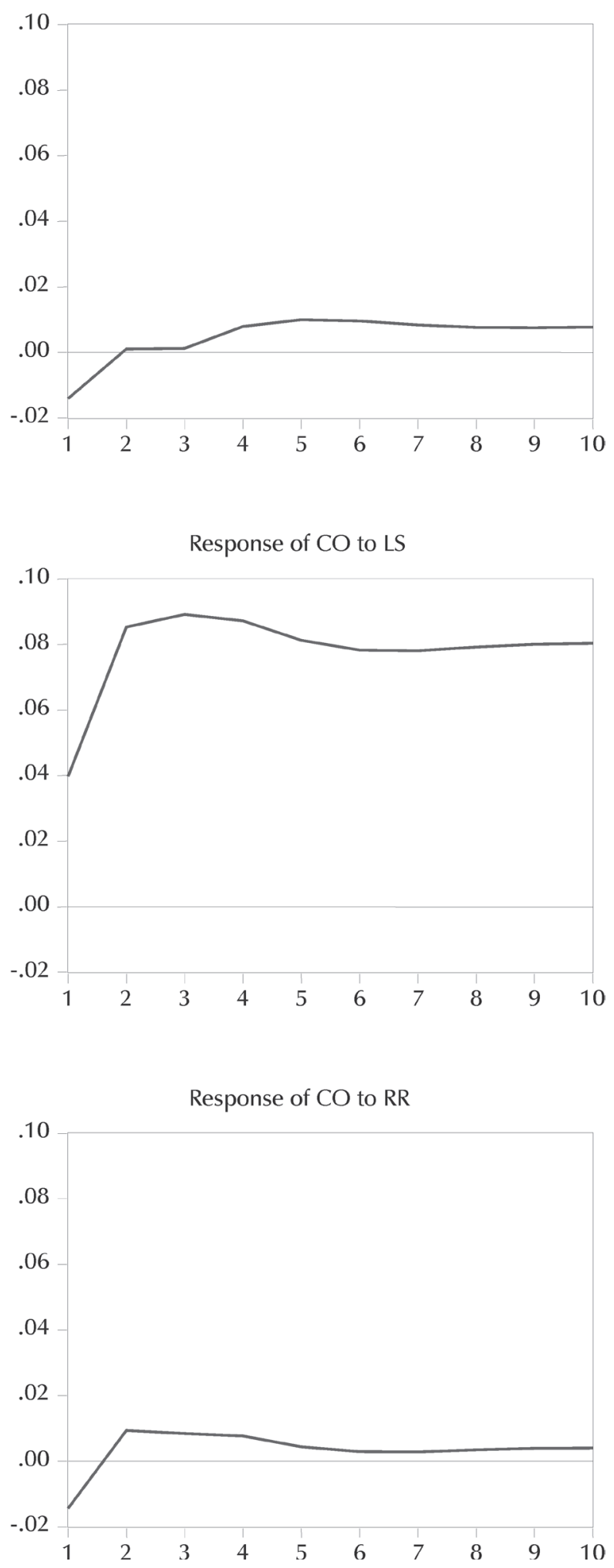